\title{
Local Effect of Neurotrophin-3 in Neuronal Inflammation of Allergic Rhinitis: Preliminary Report
}

\author{
Onur İsmi ${ }^{1}$, Cengiz Özcan ${ }^{1}$, Tuba Karabacak ${ }^{2}$, Gürbüz Polat ${ }^{3}$, Yusuf Vayisoğlu ${ }^{1}$, Taylan Güçlütürk ${ }^{4}$, \\ Kemal Görür ${ }^{1}$
}
${ }^{1}$ Department of Otorhinolaryngology, Mersin University Faculty of Medicine, Mersin, Turkey ${ }^{2}$ Department of Pathology, Mersin University Faculty of Medicine, Mersin, Turkey ${ }^{3}$ Department of Medical Biochemistry, Mersin University Faculty of Medicine, Mersin, Turkey ${ }^{4}$ Department of Otorhinolaryngology, Gaziantep State Hospital, Gaziantep, Turkey

Background: Allergic rhinitis is a common inflammatory nasal mucosal disease characterized by sneezing, watery nasal discharge, nasal obstruction and itching. Although allergen-specific antibodies play a main role in the allergic airway inflammation, neuronal inflammation may also contribute to the symptoms of allergic rhinitis. Neuronal inflammation is primarily caused by the stimulation of sensory nerve endings with histamine. It has been shown that neurotrophins may also have a role in allergic reactions and neuronal inflammation. Nerve growth factor, neurotrophin 3 (NT-3), neurotrophin $4 / 5$ and brain-derived neurotrophic factor are members of the neurotrophin family. Although nerve growth factor and brain-derived neurotrophic factor are well studied in allergic rhinitis patients, the exact role of Neurotrophin-3 is not known.

Aims: To investigate the possible roles of neurotrophin-3 in allergic rhinitis patients.

Study Design: Case-control study.

Methods: Neurotrophin-3 levels were studied in the inferior turbinate and serum samples of 20 allergic rhi- nitis and 13 control patients. Neurotrophin-3 staining of nasal tissues was evaluated by immunohistochemistry and ELISA was used for the determination of serum Neurotrophin-3 levels.

Results: Neurotrophin-3 staining scores were statistically higher in the study group than in the control patients $(p=0.001)$. Regarding serum Neurotrophin-3 levels, no statistically significant difference could be determined between allergic rhinitis and control patients $(p=0.156)$. When comparing the serum NT-3 levels with tissue staining scores, there were no statistically significant differences in the allergic rhinitis and control groups $(\mathrm{p}=0.254$ for allergic rhinitis and $\mathrm{p}=0.624$ for control groups).

Conclusion: We suggest that Neurotrophin-3 might affect the nasal mucosa locally without being released into the systemic circulation in allergic rhinitis patients. Keywords: Airway, allergic rhinitis, inflammation, neuronal, neurotrophin-3, rhinitis

This study is presented as an oral presentation in $31^{\text {th }}$ Turkish National Congress of Otolaryngology and Head and Neck Surgery, 28 October - 1 November 2009, Antalya, Turkey.

Address for Correspondence: Dr. Onur İsmi, Department of Otorhinolaryngology, Mersin University Faculty of Medicine, Mersin, Turkey Phone: +90 5057273209 e-mail: dronurismi@gmail.com

Received: 13.11.2014 Accepted: 22.04.2015 • DOI: 10.5152/balkanmedj.2015.151028

Available at www.balkanmedicaljournal.org 
Allergic rhinitis (AR) is an IgE-mediated inflammatory disorder induced after exposure to environmental allergens. Characteristic symptoms include rhinorrhea, nasal itching, sneezing, and nasal congestion (1). Also, allergic airway inflammation and hyper-responsiveness to nonspecific stimuli is controlled by neuronal mechanisms in AR patients (2). One of the alternative pathways in the pathogenesis of AR is neuronal inflammation caused by the stimulation of sensory nerve endings with histamine. Histamine also causes the release of neurotransmitters such as neurokinin A (NKA), Substance P (SP) and calcitonin gene related peptide (CGRP) (3). SP has effects on mast cell degranulation, increased vascular permeability, mucus secretion, leukocyte chemotaxis, fibroblast proliferation, and cytokine (IL-1 $\beta, 2,3,4,5$ and 6 and TNF- $\alpha$ ) synthesis, which contribute to the symptoms of AR $(4,5)$. Recently, new molecules and histamine receptors have been found for AR pathogenesis. Histamine 4 receptor (H4R) is a new histamine receptor which is expressed by hematopoietic cells such as dendritic cells, $T$ cells, mast cells, and peripheral leukocytes. It has been shown to be effective in the cascade of allergic reactions and $\mathrm{H} 4 \mathrm{R}$ receptors may have a role in allergic diseases (6). It has also been shown that neurotrophins may play a role in allergic and neuronal inflammation (7-11).

Neurotrophins are a group of nerve growth factors which are primarily responsible for the growth and differentiation of nervous tissues. Nerve growth factor (NGF), Neurotrophin-3 (NT-3), neurotrophin 4/5 and brain-derived neurotrophic factor (BDNF) are members of the neurotrophin family [5]. NGF specifically binds to its receptor Tropomyosin receptor kinase (Trk) A, BDNF and NT 4/5 bind to the Trk B receptor and NT-3 specifically binds to the Trk C receptor (8). It has been suggested that they may play a role in the pathogenesis of allergic reactions because of the high serum levels of NGF and BDNF in patients with allergic diseases $(12,13)$. Some neurotrophins like BDNF and NGF are studied in AR and their potential effects are shown, but the probable role of NT-3 in AR is not actually known $(3,14)$. In this study, we aimed to investigate the possible role of NT-3 in allergic rhinitis patients using serum levels and immunohistochemical examination of NT-3 in nasal mucosal tissue.

\section{MATERIALS AND METHODS}

Local ethical committee approval was acquired for our study. Written informed consent from patients was obtained in both the AR and control groups. Power analysis of the study was performed as outlined by previous published articles concerning the relationship between neurotrophins and allergic rhinitis. The result of the power analysis was 6 for each group.
We included 20 patients with AR and 13 control group patients with concha bullosa.

There were eight $(40 \%)$ male and twelve $(60 \%)$ female patients in the AR group. The age of AR patients was between 21 and 41 and the mean age was 30.3 years. In the control group, there were eleven $(84.6 \%)$ males and two (15.4\%) females. The age of control group was between 18 and 40, with a mean age of 28 years. There was a slight difference $(\mathrm{p}=0.011)$ between groups regarding sex, whereas there was no statistically significant difference between groups regarding the age of patients $(\mathrm{p}=0.306)$.

Nasal endoscopy was performed for all patients and the control group using $0^{\circ}$ and $30^{\circ}$ rigid telescopes. The skin prick test was performed for all AR group patients. Total and specific blood IgE levels (N-Latex Mono, Germany) were also measured for the diagnosis of AR. Sixteen allergens including positive and negative controls were used in the skin prick test (Stallergenes ${ }^{\circledR}$, France). Control group patients were selected from individuals who had been operated on for concha bullosa of the middle turbinate without rhinitis symptoms using paranasal sinus computerized tomography and nasal endoscopic examination findings. Patients with systemic diseases including rheumatoid arthritis, diabetes mellitus, hypo/hyperthyroidism, hypertension, and neurological diseases such as Parkinsonism, chorea, etc. were excluded from the study as control group patients. Inclusion and exclusion criteria for the study group patients are shown in Table 1.

TABLE 1. Study group patient selection criteria

\begin{tabular}{l}
\hline Inclusion criteria for study \\
\hline Age between $16-45$ years \\
Positive skin prick test or \\
Positive result of at least one of the serum specific IgE values \\
Symptoms for more than one year \\
No infection signs on nasal endoscopy \\
Exclusion criteria for study \\
\hline Previous systemic corticosteroid usage at most one month before \\
Previous nasal corticosteroid usage at most one month before \\
Previous nasal sodium cromoglicate or neodocromyl sodium usage at most \\
one month before \\
Previous nasal or systemic antihistaminic usage at most one month before \\
Infection signs on nasal endoscopy \\
Pregnancy or lactation \\
Nasal polyp \\
Systemic diseases including rheumatoid arthritis, diabetes mellitus, hypo/ \\
hyperthyroidism, hypertension, neurological diseases such as Parkinson- \\
ism, chorea, etc.
\end{tabular}




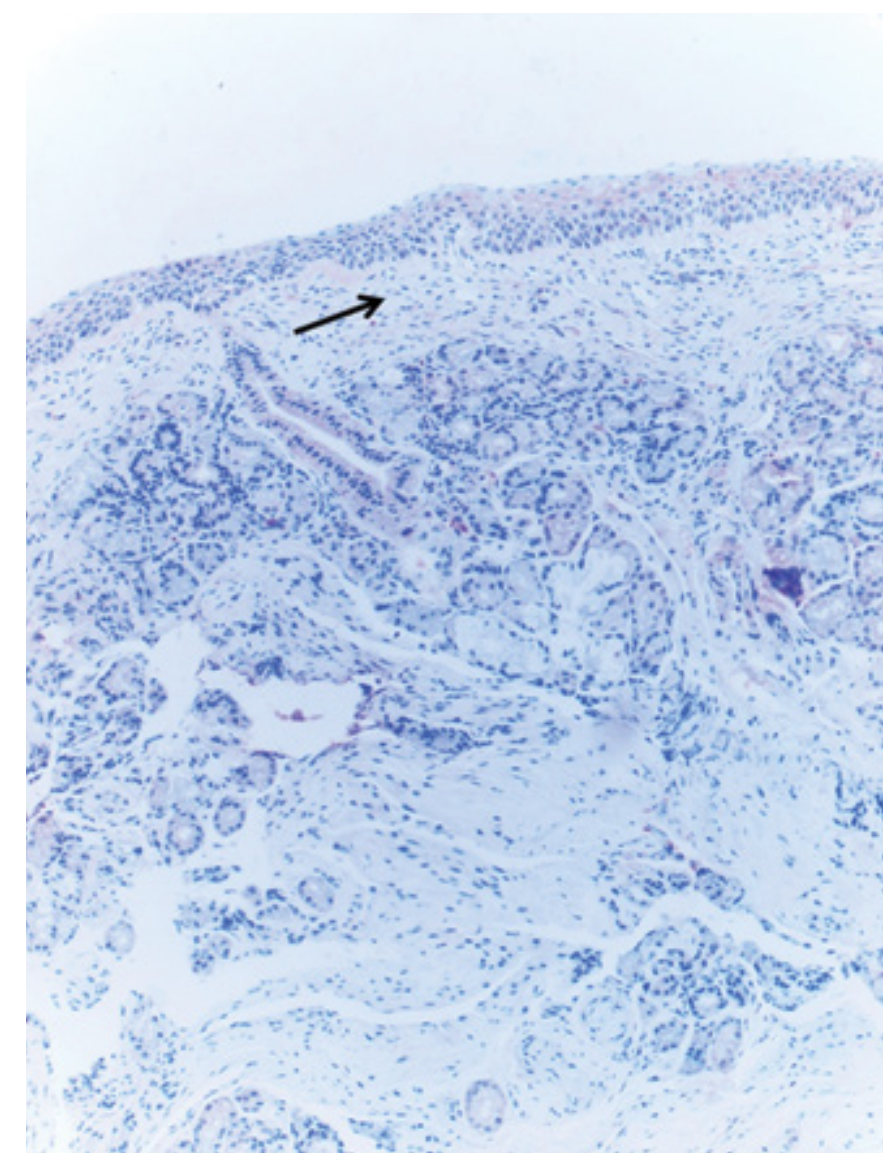

FIG. 1. Very rare $(+1)$ staining of NT-3 in the nasal mucosa (black arrow shows NT-3 staining in interstitial matrix)

Inferior turbinate biopsies for NT-3 staining levels

After providing information about the biopsy procedure to the AR patients, $10 \%$ lidocaine spray was administered to the inferior turbinates. Mucosal samples were taken from the inferior turbinate using microcup forceps. For the control group, the concha bullosa mucosa was excised during surgery under general anesthesia. The biopsy specimens and concha bullosa mucosa were fixed in $10 \%$ formalin solution. Five $\mu \mathrm{m}$ sections were obtained from formalin-fixed, paraffinembedded tissues of all biopsies and routine H\&E staining was performed. The sections were immunostained for NT-3 (Santa Cruz, Texas, USA, dilution 1:200) according to the instructions of the manufacturer, as described by Arellano et al. (15). For the negative control, specimens were processed in the absence of a primary antibody. The staining of NT-3 was observed in interstitial matrix. Briefly, the intensity of immunostaining was analyzed. The staining intensity was scored semi-quantitatively in five groups: very rare $(+1)$, mild $(+2)$, moderate $(+3)$, severe $(+4)$ and very severe $(+5)$; this was following microscopic examination as outlined by Raap et al. (16). In contrast to their method, the mildest staining score

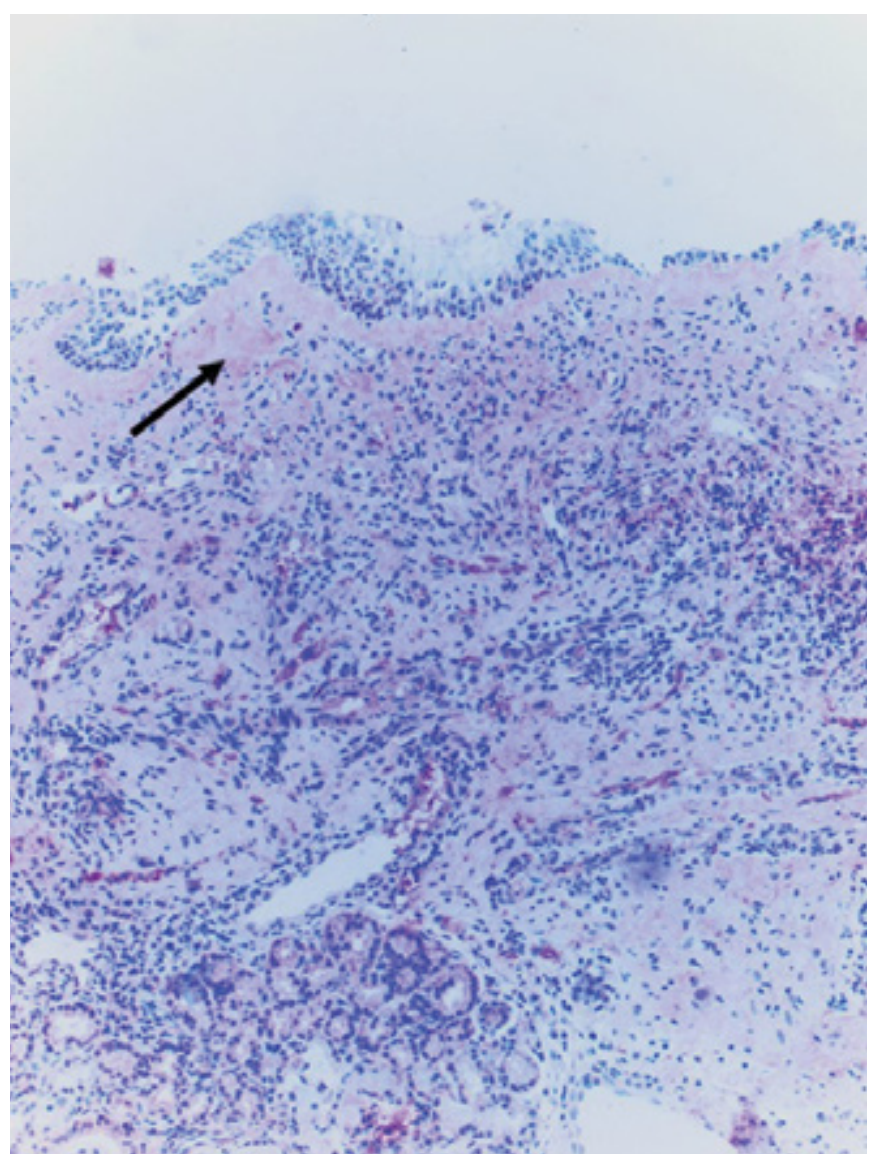

FIG. 2. Very severe $(+5)$ staining of NT-3 in the nasal mucosa (black arrow shows NT-3 staining in interstitial matrix)

was +1 , since all of our tissue biopsies showed more or less staining with NT-3. The pathologist was blinded to the group of tissue samples during immunohistochemical analysis. Very rare and very severe staining levels in the tissue specimens are shown in Figures 1 and 2, respectively.

\section{Measurement of serum NT-3 levels}

Venous blood samples were collected from patients for the measurement of serum levels of NT-3 by using an enzymelinked immunosorbent assay (ELISA). Serum NT-3 level was measured using a sandwich-ELISA kit (ChemiKine, USA) with the instructions described by Zhang et al. (17). The results were assessed as $\mathrm{pg} / \mathrm{mL}$.

\section{Statistical analysis}

Statistical analysis was performed using SPSS version 16.0 (SPSS Inc. Chicago/USA-2007). The Mann-Whitney U test was used to compare the serum NT-3 levels of the two groups because the AR group did not have a normal distribution. The Mann-Whitney $U$ test was also used for the comparison of nasal tissue NT-3 staining levels as a nonparametric test. 
TABLE 2. NT-3 staining scores of nasal tissue biopsies and serum NT-3 levels (pg/mL) of AR and control groups

\begin{tabular}{|c|c|c|c|c|}
\hline Patient Number & $\begin{array}{l}\text { AR group nasal tissue } \\
\text { staining scores }(n=20)\end{array}$ & $\begin{array}{l}\text { Control group nasal tissue } \\
\text { staining scores }(n=13)\end{array}$ & $\begin{array}{l}\text { AR serum NT-3 } \\
\text { levels }(n=20)\end{array}$ & $\begin{array}{l}\text { Control group serum } \\
\text { NT-3 levels }(n=13)\end{array}$ \\
\hline 1 & +3 & +2 & 54.07 & 127.7 \\
\hline 2 & +3 & +2 & 491.9 & 120.6 \\
\hline 3 & +5 & +3 & 7.678 & 237.2 \\
\hline 4 & +3 & +1 & 10.27 & 107.5 \\
\hline 5 & +3 & +2 & 27.59 & 135.8 \\
\hline 6 & +5 & +2 & 137.1 & 137.8 \\
\hline 7 & +3 & +2 & 445.2 & 321.4 \\
\hline 8 & +4 & +1 & 498.3 & 141.1 \\
\hline 9 & +3 & +1 & 15.22 & 348.4 \\
\hline 10 & +3 & +1 & 66.25 & 52.38 \\
\hline 11 & +5 & +2 & 224.5 & 95.63 \\
\hline 12 & +1 & +2 & 57.44 & 351.6 \\
\hline 13 & +1 & +2 & 6.738 & 93.75 \\
\hline 14 & +1 & & 13.98 & \\
\hline 15 & +3 & & 93.75 & \\
\hline 16 & +3 & & 257.9 & \\
\hline 17 & +3 & & 9.037 & \\
\hline 18 & +2 & & 111.3 & \\
\hline 19 & +3 & & 178.8 & \\
\hline 20 & +3 & & 153.2 & \\
\hline $\mathrm{p}$ values & 0.001 & & 0.156 & \\
\hline
\end{tabular}

AR: allergic rhinitis; NT-3: neurotrophin 3

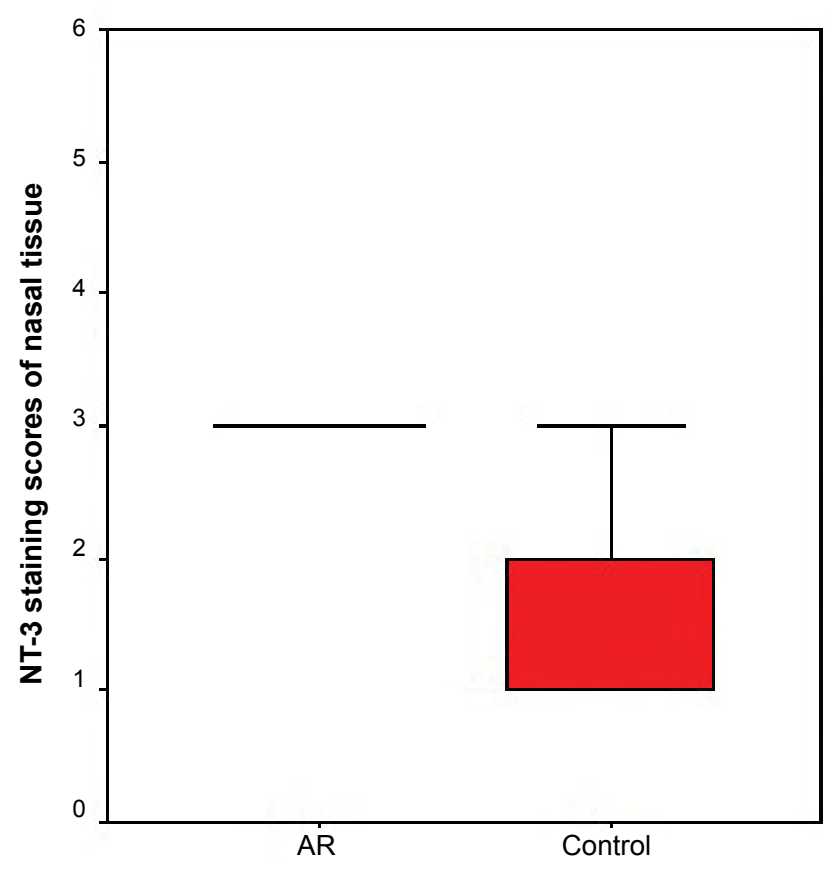

FIG. 3. Median values of tissue NT-3 staining levels of AR patients and control group (NT-3: neurotrophin 3; AR: allergic rhinitis)
Correlation coefficient was used for comparing serum levels with tissue staining scores.

\section{RESULTS}

NT-3 staining levels of nasal tissue biopsy specimens of AR patients were higher than in the control group $(\mathrm{p}=0.001)$. Median values of nasal tissue NT-3 staining of AR and control groups were +3 and +2 , respectively, as shown in Figure 3 .

When serum NT-3 levels of AR patients and the control group were compared, there was no statistically significant difference between the two groups ( $\mathrm{p}=0.156$ ). Serum NT-3 levels and NT-3 staining scores of the AR and control groups are given in Table 2. Median values of the AR and control group serum NT-3 levels are given in Figure 4.

Regarding a comparison of nasal mucosa staining scores with serum NT-3 levels, there were no statistically significant differences in the AR and control groups ( $\mathrm{p}=0.254$ for $\mathrm{AR}$ and $\mathrm{p}=0.624$ for the control group). 
TABLE 3. Studies concerning the role of neurotrophins in Allergic Rhinitis

\begin{tabular}{|c|c|c|c|}
\hline Author & $\begin{array}{l}\text { Published } \\
\text { year }\end{array}$ & $\begin{array}{l}\text { Studied Neurotrophin type (s) } \\
\text { and methods }\end{array}$ & Result \\
\hline $\begin{array}{l}\text { Sanico } \\
\text { et al. (22) }\end{array}$ & 2000 & $\begin{array}{l}\text { NGF (Nasal lavage fluid with protein electrophoresis } \\
\text { and ELISA before and after nasal provocation) }\end{array}$ & $\begin{array}{l}\text { NGF expression in nasal fluid is increased in AR and there is } \\
\text { a dose dependent increase after nasal provocation }\end{array}$ \\
\hline $\begin{array}{l}\text { Raap } \\
\text { et al. (16) }\end{array}$ & 2008 & $\begin{array}{l}\text { NGF, BDNF (serum with ELISA and tissue biopsy with } \\
\text { immunohistochemistry before and after nasal provocation) }\end{array}$ & $\begin{array}{l}\text { NGF and BDNF expression increases in nasal tissue after nasal pro- } \\
\text { vocation, but increment in serum levels is not statistically significant. }\end{array}$ \\
\hline $\begin{array}{l}\text { Raap } \\
\text { et al. (23) }\end{array}$ & 2008 & $\begin{array}{l}\text { NGF, BDNF, NT-3 (peripheral blood cytofluorometry and } \\
\text { chemotaxis for analysis of neurotrophin receptors Trk A, B, C.) }\end{array}$ & Neurotrophin receptors Trk A, B and C are up-regulated in AR \\
\hline $\begin{array}{l}\text { Gelincik } \\
\text { et al. }(2)\end{array}$ & 2012 & $\begin{array}{l}\text { NGF ( tissue biopsy with immunofluorescence } \\
\text { and immunohistochemistry) }\end{array}$ & $\begin{array}{l}\text { NGF expression increases in both AR and idiopathic rhinitis in the } \\
\text { nasal tissue }\end{array}$ \\
\hline $\begin{array}{l}\text { Ismi } \\
\text { et al.* }\end{array}$ & $\begin{array}{l}\text { Presented } \\
\text { study }\end{array}$ & $\begin{array}{l}\text { NT-3 ( Nasal tissue biopsy with immunohistochemistry } \\
\text { and serum with ELISA) }\end{array}$ & $\begin{array}{l}\text { NT-3 staining levels in nasal tissue are higher in AR group, but } \\
\text { serum levels are not statistically significant }\end{array}$ \\
\hline
\end{tabular}

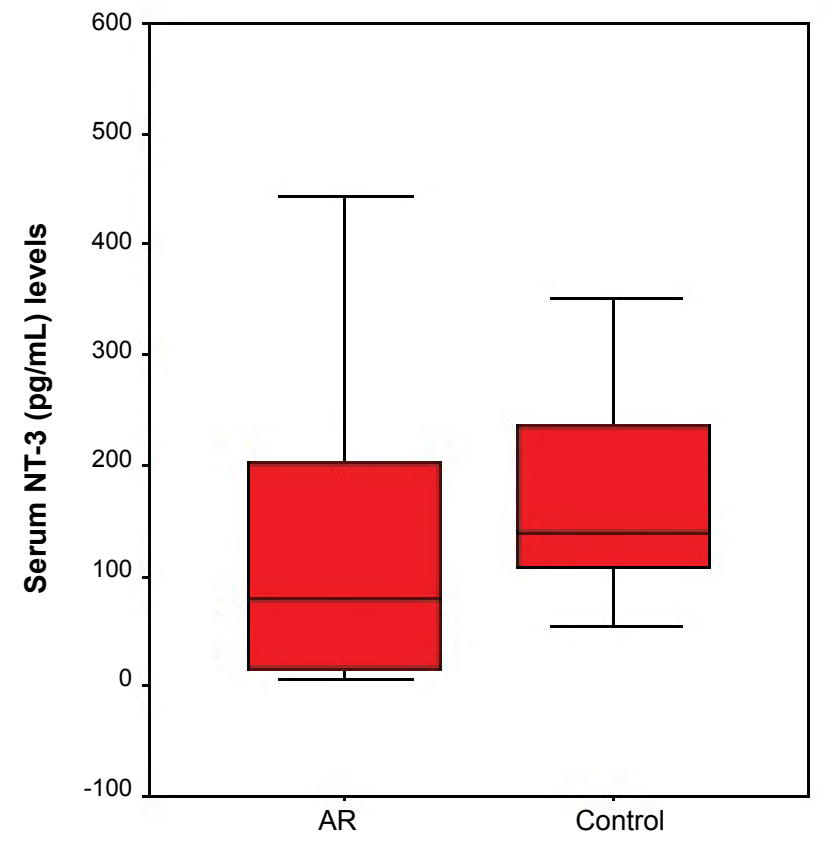

FIG. 4. Median serum NT-3 levels of AR and control groups (NT-3: neurotrophin 3, AR: allergic rhinitis)

\section{DISCUSSION}

Allergic rhinitis (AR) is the most common atopic disease, the pathology and symptoms of which are well known. AR occurs in a type 1 hypersensitivity reaction in which the cardinal symptoms of rhinitis (sneezing, watery nasal discharge, nasal obstruction and itching) are initiated by mast cell degranulation and histamine release $(18,19)$. In addition to these wellknown pathways, alternative pathways are also responsible for the pathogenesis of AR.

Neurotrophins are proteins which have similar receptor affinities and biological effects. The prototype of the neuro- trophin family is NGF. BDNF, NT-3 and NT- $4 / 5$ are the other members (7). Although neurotrophins show their effects primarily on the nervous system after binding to their receptors, they have also some effects in allergic inflammation (7-11). Increasing levels of neurotrophins in bronchoalveolar lavage fluid after allergen exposure in allergic asthmatic patients was shown. The source of neurotrophins in allergic asthmatic patients are airway epithelium, alveolar and interstitial macrophages and smooth muscle cells $(7,20)$. Neurotrophins contribute to allergic inflammation by increasing Th-2 activity. In rat models, neurotrophin Trk-C receptors are found in Th-2 lymphocytes, but not in Th-1 (7). It has also been shown that neurotrophins can contribute to inflammatory mediator secretion in allergic diseases (20). Neurotrophin mRNA levels were studied on blood eosinophils in allergic asthmatic patients and mRNA levels were higher in the allergic group than in the control group (21). Neurotrophins have multiple effects such as increasing mast cell number, basophil degranulation, upregulation of cytokine synthesis from mast cells, macrophages and granulocytes, increasing survival of plasma cells, eosinophil activation and chemotaxis in allergic reactions (7-11).

Studies concerning the roles of neurotrophins in AR patients have mainly focused on NGF. It has been shown that NGF levels of nasal lavage fluid were higher (22) and NGF and BDNF were overexpressed in nasal tissue of AR patients (16). Raap et al. (23) showed that eosinophil apoptosis is inhibited when eosinophils are stimulated by NT-3. Recently, Gelincik et al. (2) showed that levels of NGF and TrkA receptors were higher in AR patients. These findings showed that neurotrophins may play a role in AR pathogenesis. Articles concerning the relationship between AR and neurotrophins are summarized in Table 3.

IL-5-induced eosinophils actively release mRNA for production of NGF and NT-3 (24). After the activation of Trk A, 
$\mathrm{B}$ and $\mathrm{C}$ receptors of neurotrophins, which are found on eosinophils, the secretion of IL-4 from eosinophils is increased (25). After nasal provocation with an allergen in AR patients, BDNF expression in nasal mucosa and NGF expression in peripheral nerves and nasal lavage fluid are increased (26). These findings suggest that activation of neurotrophins may be an alternative pathway in AR pathogenesis.

In our study, we found that NT-3 staining levels of nasal mucosa were higher in the AR group than in the control group; this finding is similar to the literature regarding other neurotrophins $(2,16,22)$ Increases in serum neurotrophin levels in allergic diseases has also been shown $(12,16)$, whereas, in the study of Raap et al. (16), this increase was not statistically significant both before and after nasal provocation tests. Furthermore, it is also known that neurotrophins have autocrine or paracrine features. They may show their effects either locally, where they are synthesized, or in an adjacent site $(7,21)$. In our study, levels of serum NT-3 were higher in the control group, but the results were not statistically significant. Also, there was no statistically significant difference between serum NT-3 levels and nasal mucosa NT-3 staining scores in the AR group. This situation may be explained by the local production of NT-3 in nasal mucosa. It may show their effects on the local site without joining the systemic circulation in AR patients. The small sample size and possibility of taking serum samples in the non-allergic season may have affected the results of our study. There was a slight sex difference between groups in our study $(\mathrm{p}=0.011)$, but, to the best of our knowledge, there is no known study showing the difference of serum NT-3 levels among healthy human subjects with different genders.

The limitations of our study were getting samples of serum and nasal tissues shortly after the skin prick test and the gender profile of our groups.

In conclusion, besides neurotrophins, including NGF and BDGF, whose probable effects were previously shown in AR, NT-3 might also play a role in AR pathogenesis. Additional studies including larger groups of patients with the same gender profile may be more supportive of the effect of NT-3 in the neuronal inflammation of AR.

Ethics Committee Approval: Ethics committee approval was received for this study from the Local Ethics Committee.

Peer-review: Externally peer-reviewed.

Informed consent: Written informed consent from patients was obtained in both the AR and control groups.

Author contributions: Concept - O.İ., C.Ö., T.K., G.P., Y.V., T.G., K.G.; Design - O.İ., C.Ö., T.K., G.P., Y.V., T.G., K.G.; Supervision O.İ., C.Ö., T.K., G.P., Y.V., T.G., K.G.; Materials - O.İ., C.Ö., T.K., G.P., Y.V., T.G., K.G.; Data Collection \&/or Processing - O.İ., C.Ö., T.K., G.P., Y.V., T.G., K.G.; Analysis \&/or Interpretation - O.İ., C.Ö.,
T.K., G.P., Y.V., T.G., K.G.; Literature Search - O.İ., C.Ö., T.K., G.P., Y.V., T.G., K.G.; Writing - O.I., C.Ö., T.K., G.P., Y.V., T.G., K.G.; Critical Reviews - O.İ., C.Ö., T.K., G.P., Y.V., T.G., K.G.

Acknowledgements: We thank to Dr. Gülhan Örekici Temel for statistical analysis of the results.

Conflict of Interest: No conflict of interest was declared by the authors.

Financial Disclosure: Financial support of this study was achieved by our University Academic Research Project Unit with number: BAP-TF CTB(Oİ) 2007-1 TU.

\section{REFERENCES}

1. Wilson KF, Spector ME, Orlandi RR. Types of rhinitis. Otolaryngol Clin N Am 2011;44:549-59. [CrossRef]

2. Gelincik A, Aydin F, Ozerman B, Erguven M, Aydin S, Bilir A, et al. Enhanced nerve growth factor expression by mast cells does not differ significantly between idiopathic and allergic rhinitis. Ann Allergy Asthma Immunol 2012;108:396-401. [CrossRef]

3. Sarin S, Undem B, Sanico A, Togias A. The role of the nervous system in rhinitis. J Allergy Clin Immunol 2006;118:999-1016. [CrossRef]

4. Baraniuk JN, Druce HM. Neuroregulation of mucosal vasculature. In: Holgate ST, Busse WW, editors. Inflammatory mechanisms in asthma. Newyork: Marcel Dekker; 1998:619-37.

5. Kim D, Baraniuk JN. Neural aspects of allergic rhinitis. Curr Opin Otolaryngol Head Neck Surg 2007; 15:268-73. [CrossRef]

6. Takahashi Y, Kagawa Y, Izawa K, Ono R, Akagi M, Kamei C. Effect of histamine $\mathrm{H} 4$ receptor antagonist on allergic rhinitis in mice. Int Immunopharmacol 2009;9:734-8. [Cross Ref]

7. Nockher WA, Renz H. Neurotrophins and asthma: novel insight into neuroimmune interaction. J Allergy Clin Immunol 2006;117:67-71. [CrossRef]

8. Rochlitzer S, Nassenstein C, Braun A. The contribution of neurotrophins to the pathogenesis of allergic asthma. Biochem Soc Trans 2006;34:594-9. [CrossRef]

9. Quarcoo D, Fischer TC, Peckenschneider N, Groneberg DA, Welker P. High abundances of neurotrophin 3 in atopic dermatitis mast cell. J Occup Med Toxicol 2009;4:8. [CrossRef]

10. Abram M, Wegmann M, Fokuhl V, Sonar S, Luger EO, Kerzel S, et al. Nerve growth factor and neurotrophin-3 mediate survival of pulmonary plasma cells during the allergic airway inflammation. J Immunol 2009;182:4705-12. [CrossRef]

11. Renz H. The role of neurotrophins in bronchial asthma. Eur $J$ Pharmacol 2001;429:231-7. [CrossRef]

12. Bonini S, Lambiase A, Bonini S, Angelucci F, Magrini L, Manni $\mathrm{L}$, et al. Circulating nerve growth factor levels are increased in humans with allergic diseases and asthma. Proc Natl Acad Sci U $S$ A 1996;93:10955-60. [CrossRef]

13. Raap U, Werfel T, Goltz C, Deneka N, Langer K, Bruder M, et al. Circulating levels of brain-derived neurotrophic factor cor- 
relate with disease severity in the intrinsic type of atopic dermatitis. Allergy 2006;61:1416-8. [CrossRef]

14. O'Hanlon S, Facer P, Simpson KD, Sandhu G, Saleh HA, Anand P. Neuronal markers in allergic rhinitis: expression and correlation with sensory testing. Laryngoscope 2007;117:1519-27. [CrossRef]

15. Barcena de Arellano ML, Wagner MF, Oldeweme J, Arnold J, Ebert A, Schneider A, et al. Neurotrophin expression is not affected in uteri of women with adenomyosis. J Mol Neurosci 2012;47:495-504. [CrossRef]

16. Raap U, Fokkens W, Bruder M, Hoogsteden H, Kapp A, Braunstahl GJ. Modulation of neurotrophin and neurotrophin receptor expression in nasal mucosa after nasal allergen provocation in allergic rhinitis. Allergy 2008;63:468-75. [CrossRef]

17. Zhang SH, Rush RA. Neurotrophin 3 is increased in the spontaneously hypertensive rats. J Hypertens 2001;19:2251-6. [CrossRef]

18. Pata YS, Akbas Y, Unal M, Ozcan C, Gorur K, Talas DU. Distrubution of allergens among allergic rhinitis patients living in Mersin region. Kulak Burun Bogaz Ihtis Derg 2004;13:112-5.

19. Al Suleimani YM, Walker MJ. Allergic rhinitis and its pharmacology. Pharmacol Ther 2007;114:233-60. [CrossRef]

20. Dagnell C, Kemi C, Klominek J, Eriksson P, Sköld CM, Eklund A, et al. Effects of neurotrophins on human bronchial smooth muscle cell migration and matrix metalloproteinase-9 secretion. Transl Res 2007;150:303-10. [CrossRef]
21. Noga O, Englmann C, Hanf G, Grützkau A, Seybold J, Kunkel G. The production, storage and release of the neurotrophins nerve growth factor, brain-derived neurotrophic factor and neurotrophin- 3 by human peripheral eosinophils in allergics and non-allergics. Clin Exp Allergy 2003;33:649-54. [CrossRef]

22. Sanico AM, Stanisz AM, Gleeson TD, Bora S, Proud D, Bienenstock J, et al. Nerve growth factor expression and release in allergic inflammatory disease of the upper airways. Am J Respir Crit Care Med 2000;161:1631-5. [CrossRef]

23. Raap U, Deneka N, Bruder M, Kapp A, Wedi B. Differential upregulation of neurotrophin receptors and functional activity of neurotrophins on peripheral blood eosinophils of patients with allergic rhinitis, atopic dermatitis and nonatopic subjects. Clin Exp Allergy 2008;38:1493-8. [CrossRef]

24. Kobayashi H, Gleich GJ, Butterfield JH, Kita H. Human eosinophils produce neurotrophins and secrete nerve growth factor on immunologic stimuli. Blood 2002;99:2214-20. [CrossRef]

25. Noga O, Englmann C, Hanf G, Grützkau A, Guhl S, Kunkel G. Activation of the specific neurotrophin receptors TrkA, TrkB and TrkC influences the function of eosinophils. Clin Exp Allergy 2002;32:1348-54. [CrossRef]

26. Raap U, Braunstahl GJ. The role of neurotrophins in the pathophysiology of allergic rhinitis. Curr Opin Allergy Clin Immunol 2010;10:8-13. [CrossRef] 